\title{
Why do firms change fiscal year-end?
}

Vivi Z. Zhu*

\author{
A.B. Freeman School of Business \\ Tulane University \\ June 2020 \\ zzhu4@tulane.edu
}

\footnotetext{
* I thank Gus De Franco and Gans Narayanamoorthy for patient guidance and insightful comments. I also thank Stephanie Cheng, Tom Shohfi, my fellow Ph.D. students, brown bag participants at Tulane University, and participants at 2019 AAA/Deloitte/J. Michael Cook Doctoral Consortium, and participants at 2020 AAA Southwest region/FBD meeting for helpful comments and suggestions. All errors are my own.
} 


\title{
Why do firms change fiscal year-end?
}

\begin{abstract}
Changing fiscal year-end (FYE) unequivocally impacts time-series consistency, yet firms appear to be willing to change it. Enhanced comparability with industry peers appears to be a significant driver of this change. Changing FYE to align with industry peers is associated with a significant increase in analyst coverage, the number of forecasts per analyst, and institutional ownership. Investors earn $0.28 \%$ higher return surrounding the public disclosure of such changes. Additionally, loss-making firms also appear more likely to change FYEs, ostensibly to dump losses in the less-than-12-month stub period created by the transition. Examining changes to and from December separately, I find that small firms are more likely to move to a non-December FYE, suggesting that accounting costs such as audit fees, employee overtime payment, and staff retention are a consideration in changing FYE.
\end{abstract}

Keywords: fiscal year-end, comparability, consistency, accounting choice 


\section{Why do firms change fiscal year-end?}

\section{Introduction}

A firm's fiscal year-end (FYE) communicates to stakeholders the end of the period that the firm's performance is measured. During the past four decades, more than two thousand U.S. firms have changed their FYEs, representing nearly $9.3 \%$ of the total firms in Compustat. In this study, I investigate why firms change fiscal year-end, the market reactions to the public disclosure of such changes, and the consequences induced by such changes. Most U.S. corporations choose their fiscal year to coincide with the calendar year-end (Foster, 1986) and therefore, it is likely that the motivations that drive firms to change to a December year-end differ from a change away from a December year-end. As such, I investigate them separately.

While changing FYE impacts time-series consistency, there are several reasons why a firm might still change its FYE. I investigate three primary motivations behind firms' FYE switch decisions: cross-sectional comparability, poor performance, and concerns regarding accounting costs. The Financial Accounting Standards Board (FASB) defines comparability as the quality of information that enables users to identify similarities and differences between two sets of economic phenomena (FASB 1980). Extant cross-sectional accounting comparability literature (e.g., De Franco et al., 2001; Barth et al., 2012; Young et al., 2015) focuses on the similarity of accounting functions that map economic events into accounting data. In practice, cross-sectional comparability results when two firms use the same accounting principles and implement them in similar ways (Kimmel et al., 2015).

In the United States, firms are free to choose the ending date of their fiscal year. Adopting an FYE that is different from (similar to) its industry peers lowers (raises) a firm's within industry comparability. The importance of such cross-sectional comparability has been pointed out in 
numerous situations. For example, FASB (1980, p.40) states that "investing and lending decisions essentially involve evaluations of alternative opportunities, and they cannot be made rationally if the comparative information is not available." Such demand for an improved information environment induced by comparability can motivate firms to align with their peers by switching to the FYE adopted by the majority of firms in their industry.

Management provides investors with consistent measures of the firm's business, making year over year comparisons more straightforward by maintaining the same FYE. Changing the FYE, however, reduces the time-series consistency that firms have established over the years. Without time-series consistency, investors, analysts and other stakeholders could have difficulty reconciling and comparing year-over-year results, making it harder to assess the firm's performance. Changing FYE can also be expensive. When firms decide to change FYEs, their internal accountants must prepare financial information based on both the new FYE and the old FYE. Management must file an 8-K form with the Securities and Exchange Commission to disclose this change in fiscal year-end (17 CFR Parts 228, 229) once the change is approved by the board of directors. Firms are obligated to file a return for the short tax period ("stub period") that results from the change with the Internal Revenue Service (Organizations Annual Reporting Requirements). Besides, firms are required to file a report covering the transition period (Exchange Act Rule 13a-10, 15d-13 \& FRC 102.05). For example, On February 25, 2016, Synergy Resources Corporation changed their fiscal year from the period beginning on September 1 and ending on August 31 to the period beginning on January 1 and ending on December 31. As a result, the report on 10-K filed on April 22, 2016 is a transition report and includes financial information for the stub period from September 1, 2015 through December 31, 2015 (Synergy Resources Corporation, 2016). Stakeholders need to be informed, and their concerns and questions regarding the change 
need to be addressed and alleviated. For example, Keith Hiscock, CEO of Hardman \& Co., warns that investors should start from a position of suspicion when a firm changes accounting dates (Hiscock, 2015). Auditors may work extra hours to audit the financials prepared based on both the old FYE and the new FYE.

I next examine poor performance as a driver of the FYE switch decision. Two reasons can drive poorly performing firms to make FYE change decisions. First, when a firm changes its FYE, its time-series consistency is diminished. Such diminished time-series consistency may be strategic with managers adopting a specific accounting choice for self-serving reasons. For example, executives can pick the accounting choice that inflates earnings for other private reasons. If a firm with a September year-end incurs a considerable loss in October and the profits to be made in the remaining eleven months are less likely to eliminate the drag on earnings, managers can strategically change the FYE to November and thus dump the loss in the October-November stub reporting period. Second, it is possible that changing FYEs is a by-product of a firm's decision to change its business. Poor performance forces managers to rethink operational strategies. Managers can shift FYEs to reflect the changes in operations. Therefore, I predict that poorly performing firms are more likely to switch FYE.

Last, I investigate how accounting cost concerns influence firms' FYE change decisions. With the majority of fiscal year ending in December, there is peak demand for professionals like auditors (Antle et al., 2006) and accountants, at the end of each calendar year. Accounting costs, both explicit and implicit, such as audit fees, employee overtime payment, and staff retention costs may escalate for December year-end firms as a result of such peak demand. While certain accounting costs are not publicly available, I believe that they behave similarly to what we can observe, such as audit fees. Prior literature (Francis and Wang, 2005; Antle et al., 2006; Blankley 
et al., 2012) documents that auditors charge higher fees for December year-end firms. Since audit fees tend to be concave in firm size (Simunic, 1980; Abbott et al., 2003), reduced fees should be more economically significant for smaller firms than for larger firms. Therefore, small firms have stronger incentives to decrease accounting costs by changing away from a December FYE.

Based on a sample of 212,782 firm-years from 1980 to 2018, I find evidence suggesting that improved industry comparability and poor performance are associated with firms' decisions to change FYEs. Firms with FYEs different from the industry majority are more likely to align themselves with industry peers by switching FYEs. A firm is 6.9 times more likely to change its FYE if its current FYE is not the one adopted by the majority of its peers. Besides industry comparability, poorly performing firms are more likely to change FYE. Loss making firms are $64 \%$ more likely to change FYEs compared with firms without losses. Compared with other firms with a December year-end, small firms are more likely to switch FYEs consistent with the accounting cost consideration hypothesis. If the firm size increases by one standard deviation, the firm is $4.28 \%$ less likely to change away from December.

The market, based on stock trading volumes and returns, appears to react significantly to the public disclosure of FYE changes. To mitigate confounding effects induced by other material events filed on Form 8-K, I focus on the 265 8-K filings that only contain disclosures about the FYE change. On average, investors earn $0.25 \%$ higher daily returns during the three-day event window surrounding the disclosure date compared with a non-event window. When firms align their FYEs with the predominant FYE among their industry, investors experience an average of $0.28 \%$ higher daily returns surrounding the disclosure.

Prior literature (e.g., De Franco et al., 2011; Li, 2010; Tan et al., 2011) shows that enhanced comparability is associated with an improved imformation environment, as proxied by, for 
example, increased analyst coverage. In my FYE change setting, enhanced cross-sectional comparability through the alignment of FYEs is associated with a significant increase in both analyst coverage and the number of forecasts per analyst. I also find that firms with losses are more likely to dump losses to the stub period, suggesting that such firms change FYEs, at least partially, for strategic reasons. In line with accounting cost considerations, small firms that switch away from a December FYE experience a reduction in audit fees subsequent to the changes.

This study contributes to the literature in several ways. Research on accounting choice addresses the fundamental question of whether accounting matters. My results relate to the accounting choice literature by shedding light on the determinants of, market reactions to, and the consequences induced by, the exercise of a somewhat overlooked accounting choice — fiscal yearend. Although the prior literature has investigated fiscal-year-end choice, these "levels" analyses focus primarily on the differences in firms characteristics such as size, leverage, beta, and industries, and the determinants of FYE choice. For example, Smith and Pourciau (1988) and Huberman and Kandel (1989) both document that December-end firms tend to be larger. Kamp (2002) discusses fiscal year-end changes briefly and examines whether international accounting harmonization causes a drift in fiscal year-end towards a worldwide equilibrium. He finds only a few instances of fiscal year-end changes motivated by enhancing comparability. The change setting has a number of advantages over these prior papers. Given the cost of time-series consistency, the benefit of a change must be more important to justify the switch decision. A change setting makes it possible to examine the benefits. Unlike prior papers, I have the ability to study the effect of losses, a form of bad news, on the FYE decisions. In addition, concerns regarding correlated omitted variables such as non-accounting information are alleviated in a change setting. Several types of firms are required to have a certain FYE. For instance, bank 
holding companies are required to have a December year-end. When firms change to bank holding companies, their FYE change decisions are driven by regulations, a form of non-accounting information.

Second, my study contributes to the accounting comparability literature by demonstrating an alternative mechanism to enhance industry comparability. While extant literature builds the definition of comparability on the idea of mapping from economic events to financial statements (e.g., De Franco et al., 2011; Barth et al., 2012; Young et al., 2015), my comparability measure focuses on a specific accounting choice adopted across firms.

Third, my study adds to the time-series consistency literature (e.g., McCosh, 1967; Peterson et al., 2015) by documenting the market reactions to the trade-off between improved comparability and diminished time-series consistency. It also adds to the literature by presenting evidence consistent with one potential incentive for managers to strategically reduce time-series consistency. Du and Zhang (2013) are the first to investigate firms' financial reporting practices during the stub reporting period induced by FYE changes and find that firms tend to report lower income during such periods, mainly by reporting higher operating expenses. They also find that growth firms, firms with poor stock returns, and firms with weak external and internal monitoring tend to manage earnings more. My study differs from and extends theirs in that I comprehensively examine the factors driving FYE change that cause firms to have stub reporting periods as well as the consequences induced by FYE changes.

The next section outlines the theory of accounting choice in general and the three hypotheses to be analyzed. Section 3 describes the construction of the key variables, discusses the research design, and presents the empirical test results. Section 4 presents the market reaction. Section 5 discusses the consequences induced by FYE changes. The last section concludes. 


\section{Accounting Choice Theory and Hypothesis Development}

\subsection{Accounting Choice Theory}

Modigliani and Miller (1958) suggest that in the absence of taxes, bankruptcy costs, agency costs, and asymmetric information, and in an efficient market, there should be no role for accounting choice. If accounting exists and is relevant to firms' and investors' decision-making process, then at least one of the MM conditions is violated. MM conditions are then used to derive accounting choice issues by the purpose they serve or the problem they overcome. In general, three categories of goals or motivations for accounting choice are identified: contracting, asset pricing, and influencing external parties (Fields et al., 2001; Holthausen and Leftwich, 1983; Watts and Zimmerman, 1986).

The first category of accounting choice stems from the presence of agency costs and the absence of complete markets. Accounting choice is targeted to influence one or more of the firms' contractual arrangements, and hence, it is often termed the efficient contracting perspective. Contractual arrangements such as executive compensation agreements and debt covenants are determined to alleviate the internal (owner-manager) and external (bondholder-shareholder and current owner- potential owner) agency conflicts. These contracts are frequently based on reported accounting numbers (e.g., Healy, 1985; Smith and Werner, 1979). Watts and Zimmerman (1978, 1986) posit that such contracts incentivize managers to choose among accounting choices that achieve the desired financial objectives. In line with positive accounting theory proposed by Watts and Zimmerman $(1978,1986)$, prior literature (e.g., DeAngelo et al., 1994; Dye and Verrecchia, 1995; Evans and Sridhar, 1996; Guidry et al., 1999; Healy and Palepu, 1990; Sweeney, 1994) find evidence linking management' incentives and their accounting choice. 
The second category of accounting choice, driven by information asymmetries, attempts to influence asset prices. On the one hand, managers can convey privately-held information to less well-informed parties about the timing, magnitude, and risks of future cash flows (Fields et al., 2001). On the other hand, managers in poorly-performing firms incur costs arising from lower bonus payments, a reduction in the quantity of stock options awarded, and a loss in wealth (Kothari et al., 2009). Therefore, accounting choice is also allegedly made by self-interested managers to inflate earnings, in the belief rooted in the association between earnings and share prices first documented by Ball and Brown (1968). Researchers find compelling evidence suggesting that earnings management through accounting choice influences actual share prices. For example, Perry and Williams (1994) consider managing accounting choices in the year preceding the public announcement of management buyouts and find that management manipulates discretionary accruals to understate earnings, presumably in the hope of reducing the share price. Erickson and Wang (1999) analyze firms using stock as a payment method in acquisitions. They argue that bidders relying on the stock as payment manage earnings upward whereas bidders in non-stock deals do not.

The third category is to influence external parties such as Internal Revenue Service (IRS), and government regulators to reduce or deter taxes and to avoid potential regulation. The literature considering tax motivations investigates whether firms choose accounting methods to minimize the present value of taxes. For example, Dhaliwal and Wang (1992) find that firms faced with tax rates change adjusted accounting numbers by shifting permanent and timing differences across periods to minimize the tax impact. One common weakness possessed by this literature is that they do not fully address the issue of alternative explanations. The regulation effect part of the literature focuses on accounting responses to specific constraints and indirect effects. Mayor (1990) argues 
that managers can increase the difference between the provision and charge-offs by increasing the provision or reducing charge-offs to reduce regulatory costs by increasing the capital adequacy ratio to a level regulators consider adequate. Kim and Kross (1998) investigate whether banks with low capital ratios use accounting accruals for capital ratio management. They find that banks with low capital ratios reduce their loan loss provisions and increase write-offs after the Office of the Comptroller of the Currency (OCC) and other bank regulatory agencies changed both the minimum capital requirements and the capital ratio computation.

\subsection{Hypothesis Development}

I investigate three motivations that drive firms' FYE switch decisions: cross-sectional comparability, poor expected performance, and concerns regarding accounting costs.

Rare Element Resources Ltd. changed its FYE in 2013 with "the intent ... to align the reporting of our financial results more closely with our peers." By reporting numbers in the same accounting cycle as their peers, firms can reduce information asymmetry, improve industry comparability, and facilitate investors' decision-making process.

Cross-sectional comparability is a crucial element of financial reporting. Comparability is defined by the Financial Accounting Standards Board (FASB) as the quality of information that enables users to identify similarities and differences between two sets of economic phenomena (FASB 1980). Kimmel et al. (2015) argues that comparability results when two companies use the same accounting principles and implement them in similar ways. The importance of comparability has been pointed out in numerous situations. For example, De Franco et al. (2011) show that comparability lowers the cost of acquiring information, and increases the overall quantity and quality of information available to analysts about the firm. Li (2010) suggests that enhanced comparability significantly reduces the cost of equity. Given the benefits of comparability, 
managers may sacrifice time-series consistency temporarily to improve the firm's information environment by changing FYEs if their current FYEs are not the same FYEs adopted by the majority of their peers. This argument gives rise to my first hypothesis:

H1 (Cross-sectional Comparability Hypothesis): A firm is more likely to change FYE if its original FYE is different from the predominant FYE adopted by its peers.

Further, accounting choice, driven by information asymmetries, attempts to influence firms' asset prices. Since prior research shows that management manipulate earnings (DeFond and Park, 1997; Bartov et al., 2002; Bens et al, 2003; Roychowdhury, 2006), managers could be motivated by self-serving purposes to leave losses out of the official reporting cycles strategically. If a September year-end firm incurs a considerable loss in October, it may announce in late July that it would change its FYE to November. ${ }^{1}$ As a result, the financials for October and November are then reported as the stub period. By changing the FYE, management successfully omits the two poorly-performing months. In addition, while a report for the stub period is required, comparable financials for the same stub period in previous years are not required (17 CFR $\S 240.15 d-10)$. A lack of comparable financials for the stub period makes it much more difficult to compare yearover-year performance. Compared with other firms, loss-making firms may have stronger incentives to strategically change FYEs to diminish time-series consistency and to make it harder for investors, creditors, and analysts to compare financials with previous years' results.

As an alternaive to strategic behavior, diminished time-series consistency may be an unintended by-product of the process of changing business. Since suffering from losses forces managers to rethink operational policies and strategy decisions, loss firms have stronger incentives

\footnotetext{
${ }^{1}$ Although how long it takes the board to make the FYE change decision is unobservable, on average, the decision is made and disclosed about four months before the 12-month fiscal year with the new FYE. For example, if a January year-end firm switches to a March year-end and the first full fiscal year ending in March is 2015, the switch decision is made, on average, in late November 2014.
} 
to reshape the business. Managers can switch FYEs to reflect the changes in the operations and to reduce any information asymmetries. These arguments lead to my second hypothesis:

\section{H2 (Poor Performance Hypothesis): A loss-making firm is more likely to change its FYE.}

Most U.S. corporations choose their fiscal year to coincide with the calendar year-end (Foster, 1986) and this situation leads to peak demand for professionals like auditors (Antle et al., 2006) and accountants at the end of each calendar year. As a result of this peak demand, explicit and implicit accounting costs, such as audit fees, employee overtime payments during the end of the year around the holiday season, and staff retention costs may escalate for December year-end firms. While employee overtime payments and retention costs are not publicly available, I believe that they behave similarly to what we can observe, such as audit fees. Prior literature (e.g., Rubin, 1988; Francis and Wang, 2005; Antle et al., 2006; Blankley et al., 2012) documents that auditors charge higher fees for December year-end firms. Small firms, compared with large firms, have relatively limited resources and thus have stronger incentives to save accounting costs by deviating from a December FYE. Since audit fees tend to be concave in firm size (Simunic, 1980; Abbott et al., 2003), reduced fees should be more economically important for small firms than for large firms. Thus, accounting cost concerns might incentivize small December-end firms to adopt nonDecember year-ends.

As majority of firms ending fiscal year in December, small firms may mimick other firms by switching to a December year-end. Aligning fiscal year with calendar year improve the comparability with the majority of firms. Financial statements are released around the same time for December year-end firms. As more than half of total firms ending fiscal year in December, small firms can potentially attract more attention when investors are exploring available financials. This discussion gives rise to my third hypothesis: 
H3 (Accounting Cost Hypothesis): A small December year-end firm is more likely to switch to a non-December year-end.

Note that, these hypotheses are neither mutually exclusive nor collectively exhaustive. It is possible that multiple reasons drive firms' FYE change decisions.

\section{Empirical Analysis}

\subsection{Key Variables}

3.1.1. Comparability. Since comparability is closely related to firms' FYE choice before changes are made, I develop a comparability measure based on the firm's FYE relative to industrylevel choices. A month is defined as the predominant FYE if it is adopted by the most number of firms in a given two-digit SIC industry in year $t^{2}$ Predominant is an indicator variable that equals one if the FYE of firm $i$ is the predominant FYE in an industry in year $t$, zero otherwise. ${ }^{3,4}$

3.1.2. Poor Performance. Early studies (e.g., Fama and Babiak, 1968; Ball and Watts, 1972; Lintner and Glauber, 1972; Watts and Leftwich, 1977) assume that annual accounting earnings follow a random walk. Thus, current earnings should be the best estimate of future earnings, and firms with losses in the previous year should be more likely to incur losses in the coming year

${ }^{2}$ The results and inferences are robust to alternative industry classifications such as three-digit and GICS.

${ }^{3}$ In untabulated results, I replace Predominant with two continuous measures and repeat the analysis. All results and inferences are similar. The first alternative measure is based on the percentage of firms in a given industry that employ the same FYE as firm $i$, calculated as $N_{j t k} / N_{j t}$ where $N_{j t k}$ is the total number of firms in industry $j$ with FYE $k$ in year $t, N_{j t}$ is the total number of firms in industry $i$ in year $t$. For example, assume firm $i$ in industry $j$ has a December year-end as of year $t$. If the total number of firms in industry $j$ with a December year-end is 20 including firm $i$, and a total of 100 firms exist in industry $j$ in year $t$, the comparability measure Comp for firm $i$ in industry $j$ in year $t$ equals $20 / 100$, or $20 \%$. The other alternative measure is defined as $\sum_{k}$ Salesijt $=\sum_{i k}$ Salesijt $_{\text {where Sale }}$ witk is the sales of firm $i$ with FYE $k$ in industry $j$ at time $t$.

${ }^{4}$ Since the comparability measure is based on whether the firm's current FYE is the same as the one adopted by most of the firms in the industry, a concern arises that comparability is less important when the predominant FYE is adopted by $30 \%$ of firms in an industry than when the predominant FYE is adopted by $70 \%$ of firms in an industry. If the predominant FYE is adopted by $30 \%$ of the firms in an industry, firms with non-predominant FYE may have fewer incentives to incur all the costs in order to switch FYEs compared with the situation where the predominant FYE is adopted by $70 \%$ of the firms in an industry. To mitigate this concern, I conduct a sensitivity test for the comparability measure. I define the predominant FYE as the FYE adopted by more than $50 \%$ and $75 \%$ of firms in an industry and repeat the analysis. All results and inferences are similar. 
compared with firms with no previous losses. ${ }^{5}$ If firms want to take advantage of the stub period strategically, loss-making firms are more likely to have losses in the coming year than non-lossmaking firms, and thus, have stronger incentives to change FYEs. In addition, previous losses are more likely to force managers to rethink corporate policies and reshape the business. Therefore, I operationalize poorly performing firms as firms with losses. Loss is an indicator variable that equals one if firm $i$ incurs a loss in year $t$, zero otherwise.

3.1.3. Accounting Costs. Accounting costs consist of explicit and implicit fees such as audit fees, employee overtime payments, and staff retention costs. Data on employee overtime payment and staff retention costs are not readily available. Abbott et al. (2003) demonstrate that company size is strongly associated with audit fees. Smith and Pourciau (1988) and Huberman and Kandel (1988) both document that December year-end firms tend to have larger assets. I use the natural logarithm of total assets at the end of each year to proxy for the importance of FYE-associated accounting costs, where accounting costs are more salient for small firms. ${ }^{6}$

\subsection{Data and Sample Selection}

I identify firms that change FYEs from 1979 to 2018 in the Compustat database. ${ }^{7,8}$ I further require each firm-year observation to have non-missing values for required variables. Since some of the required variables are one year lagged variables, the sample covers firm-year observations

\footnotetext{
${ }^{5}$ In my sample, if a firm incurs a loss in the previous year, the probability of incurring a loss in the next year is $75 \%$ while the probability of incurring a loss for a firm with no loss in the previous year is $17 \%$.

${ }^{6}$ In untabulated results, I replaced total assets with market capitalization. The results and inferences are similar.

${ }^{7}$ Some firms use a 52- or 53- week fiscal year. For example, Tyson Foods, Inc. uses a 52- or 53-week accounting period that ends on the Saturday closest to September 30. The FYE date in 2016 is 10/1/16, and 2017 is FYE 9/30/17. In Compustat, Tyson Foods, Inc. ends its fiscal year in September every year. In this case, I do not classify Tyson Foods, Inc. as a FYE changer in 2017.

${ }^{8}$ Since the sample in this study covers a relatively extended period, the Dot Com Bubble and the 2008 financial crisis are both included. Regulatory reforms and firm-specific changes followed after both events. During these two periods, more firms than usual would change business or experience losses. Thus, a concern arises that these two periods may drive the results. To mitigate the concern, I drop observations in the year 2001, 2002, 2008, and 2009 and replicate my main test. All results and inferences remain similar.
} 
from 1980 to 2018. I drop firms with SIC code between 6000 and 6999 because a December FYE is mandatory for several types of financial firms. ${ }^{9,10}$

Table 1 reports summary statistics. Panel A reports the FYE distribution by calendar month for all firms. Consistent with prior literature (Smith and Pourciau, 1988; Huberman and Kandel, 1988), the majority (61.2\%) of the firms adopt December as their FYE. Other calendar quarter ends (March, June, and September) also appear to be popular choices for FYE.

Panel B provides the transition matrix of firms that changed FYE. During the sample period, 2,163 firms changed their FYEs. Among firms that changed FYEs, 58\% of the firms switched to a December year-end while 19\% of the firms moved away from a December year-end. In addition, about $26 \%$ of the firms switch to calendar quarter-ends other than December.

Panel C presents FYE change by year. The number of total FYE changes steadily increases from 1980 and reaches its peak in the late 1990s. After 1998, the number of FYE changes per year decreases. During the sample period, on average 1\% of firms change their FYEs per year.

Panel D shows the predominant FYE distribution. A predominant FYE is defined as the month adopted by the largest number of firms in a two-digit SIC industry in a given year. December is the most popular predominant FYE as $68 \%$ of the industries employ a December year-end. Besides December, January and June are the next most popular predominant FYEs. ${ }^{11}$

Panel E breaks down all the FYE changes based on the predominant FYE in an industry in a given year. When the predominant FYE is identified, the other FYEs adopted are nonpredominant FYEs. Based on all the changes from 1980 to 2018, 59\% of the changes are made to

\footnotetext{
${ }^{9}$ For example, Goldman Sachs briefly discusses their justification for FYE change in Form 10-K for fiscal year ended Dec. 31, 2009 that "in connection with becoming a bank holding company, the firm was required to change its fiscal year-end from November to December."

${ }^{10}$ The results and inferences are robust to the inclusion of financial firms.

${ }^{11}$ As the predominant FYE is defined by industry and year, the predominant FYEs may differ overtime. Thus, the total number of industries in the table is larger than the actual number of industries.
} 
align with the predominant FYE. Kamp (2002) find only a few instances of FYE changes motivated by enhancing comparability. In contrast, I find that more than half of the FYE changes are consistent with enhanced industry comparability. The difference in results is likely explained by the different comparability focus in Kamp (2002). ${ }^{12}$ In addition to those firms that changed FYEs to align with industry peers, $19 \%$ of the changes are made from the predominant FYE to the non-predominant FYE while $21 \%$ of the changes are made from a non-predominant FYE to another non-predominant FYE.

\subsection{Methodology and Full Sample Results}

To test H1, and H2, I adopt the following logit specification:

$$
\begin{aligned}
\Delta \text { YYE }_{t}= & \beta_{0}+\beta_{1} \text { Predominant }_{t-1}+\beta_{2} \text { Size }_{t-1}+\beta_{3} \text { Loss }_{t-1}+\gamma_{1} \text { M\&A } A_{t-1} \\
& +\gamma_{2} \Delta \text { Segment }_{t-1}+\gamma_{3} \text { Foreign }_{t-1}+\gamma_{4} \text { Firm Age }_{t}+\text { Industry FE } \\
& + \text { Year FE }+\varepsilon
\end{aligned}
$$

where $\triangle F Y E_{t}$ is an indicator variable that equals one if the firm changes FYE in year $t$, zero otherwise. The test of $\mathrm{H} 3$ requires a different sample, which I will discuss in the next subsection.

My study includes four controls. First, when an M\&A activity is completed, the parent company needs to consolidate its subsidiaries' financial information. This situation creates an incentive for the parent and subsidiaries to align their FYEs if their FYEs are not the same prior to the merger or acquisition. ${ }^{14}$ For example, Tecnoglass Inc. stated in their annual report that "we also changed our fiscal year-end from February 28th to December 31st in order to coincide with the fiscal year-end of Tecnoglass Holding and its subsidiaries." I identify merger and acquisition

\footnotetext{
${ }^{12}$ Kamp (2002) looks at global FYE changes during 1990 to 1998 . He focuses on whether firms across the world switch to the same FYE. He finds that in the U.S., the net effect is in favor of switches to December.

${ }^{13}$ In untabulated results, I add audit fixed effects to mitigate the concern that auditors, not managers, are initiating FYE changes. The results and inferences are robust to the inclusion of auditor fixed effects.

${ }^{14}$ Among all the firms that changed FYEs, 15\% have M\&A activities. My results and inferences remain unchanged if these firms are removed from the sample.
} 
activities from the SDC Platinum database. The indicator variable $M \& A$ controls for merger and acquisitions activities.

Second, as a firm evolves, the core business may shift over time. The original FYE may not fully capture the nature of the business, and thus, it creates an incentive for managers to switch to an FYE that better measures the current business reality. For example, Pandora, one of the leading internet radio service in the States, derived their revenue from subscription fees and the sale of advertising on a computer-based platform in the past. The firm now generates a majority of their revenue from advertising on mobile and other connected devices, and they expect that advertising will comprise a substantial majority of revenue for the foreseeable future (Pandora Media Inc., 2013). As a result, Pandora changed its FYE to December in 2013 to align with the advertising industry's business cycle. To capture whether firms adjust their corporate strategy, I employ the indicator variable $\Delta$ Segment that equals one if firm $i$ 's business segments in year $t$ differ from those in year $t-1$, zero otherwise.

Third, managers in multinational firms may take geographic specific regulations into considerations when making decisions. For example, Australia has a mandatory tax period ending June 30. Most Australian firms appear to align their annual reporting to this mandatory tax period (Kamp, 2002). If a foreign branch is required to have a certain FYE and the foreign income needs to be consolidated, managers can shift the FYE to accommodate such foreign regulations. Therefore, I utilize the indicator variable Foreign to capture multinational firms' incentives to change FYEs due to geographical diversification. Foreign equals one if firm $i$ has non-zero foreign income, zero otherwise.

Last, as firms develop over time, their operating and financial reporting systems are more likely to become well established. The longer a firm exists, the less likely it is to change its FYE. 
Hence, I include Firm Age, defined as the natural logarithm of the number of years firm $i$ appears in Compustat, as an additional control. I also include industry fixed effects and year fixed effects. Industry fixed effects control for heterogeneity across industries while year fixed effects control for year-specific shocks that are common to firms with and without FYE changes.

Table 2 reports the logit results of estimating equation (1) for the full sample. The Crosssectional Comparability Hypothesis predicts that less comparable firms are more likely to change FYE. In line with this hypothesis, Predominant is negatively associated with the probability of changing FYEs. The probability of changing FYEs is $2.1 \%$ for a firm with a non-predominant FYE while the probability of a change in FYE for a firm with a predominant FYE is only $0.3 \%$, suggesting that firms with non-predominant FYEs are 6.9 times more likely to switch FYEs. The Poor Performance Hypothesis points out that a loss-making firm has stronger incentives to change FYE. As indicated by the positive and statistically significant coefficient of Loss, firms with losses in the previous year are $64 \%$ more likely to change FYEs while the probability for firms with no losses is $0.8 \%$.

\subsection{Accounting Cost Results}

In this section, I test $\mathrm{H} 3$. Before doing so, I confirm my claim that accounting costs are more important for small firms than large firms. Since data on accounting costs such as employee overtime payment and staff retention costs are not readily available, my analysis focuses on audit fees. Table 3 provides descriptive statistics for the importance of firms' audit fees relative to firm size. I use the percentage ratio of total audit fees to total assets to proxy for the relative importance of audit fees for each firm. A firm is classified as a small (large) firm if its total assets are below (above) the two-digit SIC industry median in that year. Audit fees represent a significantly higher percentage of total assets for small firms than large firms. On average, audit fees cost about $0.82 \%$ 
of total assets for small firms every year. Large firms' audit fees are only $0.14 \%$ of their total assets. The difference of $0.68 \%$ is both statistically and economically significant. Given the ratio of audit fees to total assets is significantly higher for small firms, audit fees should be more important for small firms than large firms.

To test H3, I split the sample based on December year-end. Table 4 presents the results. Column 1 tests whether small firms are more likely to switch from a December year-end. I retain those firms that deviate from a December year-end and restrict the control group to December year-end firm-year observations. The dependent variable $\triangle F Y E$ equals one if firm $i$ changes FYE from a December year-end to a non-December year-end in year $t$, zero otherwise. If small firms are more likely to change away from a December year-end to save accounting costs, we should expect the coefficient of Size to be negative.

For firms that switch away from December, Column 1 shows that the coefficient of Size is negative and statistically significant as expected. The negative relation provides evidence that smaller firms are more likely than larger firms to switch away from a December FYE. If the firm's size increases by one standard deviation, the firm is $4.28 \%$ less likely to change away from December.

As a corollary, when firms switch from non-December FYEs to a December FYE, we should expect the coefficient of Size to be non-negative. In Column 2, I conduct the same logit regression for firms that switch to a December FYE. The treatment group is limited to firms that change to a December FYE, and the control group is restricted to non-December year-end firmyear observations. The dependent variable $\triangle F Y E$ equals one if firm $i$ changes FYE from nonDecember year-ends to a December year-end in year $t$. The coefficient of Size is not statistically 
significant. I find no evidence suggesting that accounting cost considerations drive firms' decisions to switch to a December FYE.

Since auditors charge higher fees for December year-ends only, as a falsification test, accounting costs should not matter when firms change from a non-December FYE to another nonDecember FYE. I apply the same logit regression to firms that switch from a non-December FYE to another non-December FYE. $\triangle F Y E$ equals one if firm $i$ changes FYE from non-December yearend to another non-December year-end in year $t$. I restrict the control group to non-December yearend firm-year observations. Column 3 reports the results. The coefficient of Size is not statistically significant. I find no evidence supporting the prediction that accounting cost is a primary concern driving firms' decisions for non-December changes.

\section{Market Reaction}

Holthausen and Leftwich (1983) highlight that theories with contracting and monitoring costs predict that changes in accounting choices used to calculate accounting numbers have economic consequences. If FYE changes trigger significant consequences to investors, we should expect the market to react. ${ }^{15}$ More specifically, I test whether and how the market reacts to public disclosures of FYE changes.

On one hand, as comparability is a critical element highly valued by investors, and given all the benefits brought by enhanced industry comparability, when firms change FYEs for improved comparability, positive returns can be expected. If small firms switch away from a December year-end, they can enjoy reductions in accounting costs. Such reductions can benefit small firms in the long term and hence evoke positive market reactions. On the other hand, firms

\footnotetext{
${ }^{15}$ Early tests of stock reaction to changes in accounting choices (Ball, 1972; Kaplan and Roll, 1972; Sunder, 1973), however, provide no evidence suggesting the association of stock price and accounting choice changes exists, except for those changes affecting federal income taxes (e.g., LIFO-FIFO switches). Kaplan and Roll (1972) argue that investors can see through the facade, provided that the accounting choice is publicly disclosed.
} 
reduce time-series consistency and make it more difficult to reconcile with previous years' results when switching FYEs. Without consistency, the cost of analyzing year-over-year numbers increases. Further, prior research shows that greater time-series consistency is associated with lower information asymmetry (Peterson et al., 2005). Therefore, firms may experience negative returns at the time of switching regardless of the potential benefit from enhanced comparability. Moreover, investors may question whether loss-making firms are acting strategically by switching FYEs and such firms may earn negative returns. In addition, reduction in accounting costs is realized in a relatively long time horizon while the costs incurred to change FYE is upfront. Further, if the predominant FYE is December and a small firm deviates from a calendar year-end, the crosssectional comparability decreases. Negative market reaction may be evoked as a result.

To test the market reactions to FYE changes, I conduct an event study based on the 8-K that requires the disclosure of certain events under Regulation FD (17 CFR 243.100 and 243.101). Change in fiscal year-end is one aspect that requires an $8-\mathrm{K}$, hence, the filing date of $8-\mathrm{K}$ can be treated as the date that investors become aware of the FYE change. I retrieve stock returns from The Center for Research in Security Prices (CRSP) and hand collect financial information during the stub period from EDGAR.I hand collect the filing dates of 8-K disclosures from Electronic Data Gathering, Analysis, and Retrieval (EDGAR). Since EDGAR started in 1994/1995, my sample for market reactions are limited to FYE changes after 1994. As an 8-K can contain other substantial events, such as entry into or termination of a material definitive agreement and departure of directors or principal officers as two examples, I further restrict the sample to the filing dates of 8-Ks that discloses only FYE changes to remove any confounding effects. This restriction leaves me with 265 "clean" filing dates. 
Following De Franco et al. (2009), I focus on short-window reactions and test the daily average return differences between the event period and the non-event period returns to examine whether firms experience a significant stock return change after the FYE change disclosure. The event window is defined as -1 to +1 days surrounding the disclosure. The non-event window is defined as the days excluding the event period during -30 to +30 trading day. I further remove days with firm-specific news such as analyst's firm upgrades or downgrades to mitigate the effects of other confounding events. Event is the daily average for Trading Volume, Absolute Return, or Return during the event window. Trading Volume is stock volume scaled by the total number of shares outstanding. Absolute Return is the absolute value of the holding period return. Return is the raw holding period return. Nonevent is the respective daily average during the non-event window. Difference is the difference between Event and Nonevent.

Table 5, Panel A reports the results. On average, a FYE change 8-K disclosure triggers significant market reactions. About $0.09 \%$ more of the total number of shares outstanding are traded daily surrounding such disclosures. Absolute Return and Return during the event window are $0.46 \%$ and $0.25 \%$ higher than those during the nonevent window. I further split the sample based on the key variables to test the market reaction to each potential driver. Panel B shows the results. When firms are aligned with the predominant FYE after the change, investors earn a $0.28 \%$ higher daily return compared with the non-event window. However, when firms deviate from the predominant FYE, no significant return difference is found. Investors earn significantly higher returns during the event window regardless of the losses incurred in the previous year. When small firms deviate from or align with a December year-end, no significant market reaction is evoked. 
My evidence suggests that the market reacts significantly to FYE changes. The positive returns during the event window indicate that investors value comparability in the comparabilityconsistency trade-off.

\section{Consequences of FYE change}

Considering the importance of time-series consistency and the expenses firms need to incur when changing FYEs, firms expect the benefits to outweight the costs when making switch decisions. I next examine the benefits and consequences of FYE changes to investigate whether firms achieve their intended goals through switching FYEs.

\subsection{Analysts' Coverage and Institutional Ownership}

Lang and Lundholm (1996) suggest that analysts primarily interpret information as opposed to convey new information. Different FYEs adopted by firms in the same industry demand analysts to exert more efforts to compare operating results among firms. It may even create a barrier to entry of analysts' coverage for firms with FYEs that are other than the predominant FYE of their peers. Further, prior literature (e.g., De Franco et al., 2011; Tan et al., 2011) document that improved comparability leads to more analysts covering the firm. As firms align their FYEs with the predominant FYE adopted by their peers, it becomes easier for analysts to interpret crosssectional information, and thus, such firms may attract more analysts' covering the firms after the FYE switch via a lowered cost of acquiring information and ultimately improve the information envonroment by shifting FYEs. In addition, financial statements tend to be released around the same time with the FYE alignment. The availability of financial statements may serve as a reminder to update peers' forecasts as analysts explore and compare cross-sectional performance. Therefore, FYE alignment can increase the number of forecasts per analyst. I further hypothesize that aligning FYEs with peers through changing FYEs is associated with improved information 
environment. I use the number of analysts covering the firm and the number of forecasts per analyst to proxy for the information environment.

To test whether aligning with the predominant FYE is associated with more analysts covering the firm, I estimate the following OLS regressions:

$$
\begin{aligned}
\text { Number Analysts }= & \beta_{0}+\beta_{1} \text { Improved }+\beta_{2} \text { Improved } \times \text { Post }+\beta_{3} \text { Worsened } \\
& +\beta_{4} \text { Worsened } \times \text { Post }+\beta_{5} \text { Post }+\beta_{6} \text { Size }+\beta_{7} \text { Book to Market } \\
& +\beta_{8} \text { ROA }+\beta_{9} \text { Depreciation }+\beta_{10} R \& D+\beta_{11} \text { Volume } \\
& +\beta_{12} \text { Volatility Return }+\beta_{13} \text { Volatility Earning }+ \text { Industry FE } \\
& + \text { Year FE }+\varepsilon
\end{aligned}
$$

Number Analysts is the logarithm of 1 plus the number of analysts issuing at least one earnings forecast for the firm in a given year in $\mathrm{I} / \mathrm{B} / \mathrm{E} / \mathrm{S}$. Improved is an indicator variable that equals one if firm $i$ changes from a non-predominant FYE to the predominant FYE, and zero otherwise. Worsened is an indicator variable that equals one if firm $i$ changes from a predominant FYE to a non-predominant FYE, and zero otherwise. Post is an indicator variable that equals one if the year is after the year of FYE change, and zero otherwise.

In estimating equation (2), I control for factors that motivate analyst coverage previously documented in the literature (e.g., Barth et al., 2001; Bhushan, 1989; Brennan and Hughes, 1991; De Franco et al., 2011; Lang and Lundhold, 1996; O’Brien and Bhushan, 1990). Book to Market is the book to market ratio of equity. $R O A$ is the return on assets. Depreciation is depreciation expense divided by total sales. $R \& D$ is research and development expense divided by total sales. Following Barth, Kaznick, and McNichols (2001), I industry adjust $R \& D$ and Depreciation by subtracting the respective two-digit SIC industry mean value. Volume is the logarithm of trading 
volume in millions of shares during the year. Volatility Earning is the standard deviation of 16 quarterly earnings. Volatility Return is the standard deviation of 48 months of stock returns.

To examine whether firms' improved (worsened) comparability is associated with an increase (decrease) in analyst coverage and the number of forecasts per analyst, I employ $\mathrm{I} / \mathrm{B} / \mathrm{E} / \mathrm{S}$ to develop my key variables. Since I/B/E/S has few forecasts before 1982, I restrict the test to firmyear observations after 1982. I further require firms to have non-missing data for the two years before the FYE change, the year of the change, and two years subsequent to the FYE change. This restriction leaves me with 195 changes to the predominant FYE and 36 changes from the predominant FYE. I match each treatment firm (firms that changes FYEs) with a control industry peer of the closest size, profitability in the previous year. I further require the matched controls to have the same value for Predominant as the treatment firms prior to the FYE switch. For example, if a firm's FYE is non-predominat prior to the change, the matched control's FYE needs to be nonpredominant as well. I then require that the matched controls are in the same industry as the treatment firms.

Table 6 presents the results of estimating Equation (2). Column 1 shows the results for Number Analyst. The variable of interest is the interaction term between Improved and Post, which captures the extent to which the number of total analysts that issue at least one earnings forecast for the firm changes following the FYE switch. In line with the benefit induced by enhanced comparability documented in prior literature, the coefficient of the interaction term is positive and statistically significant. This positive coefficient suggests that, on average, when firms are aligned with their peers following the FYE change, they attract more analysts to cover them. After the changes, firms aligned with peers are associated with an increase in the logarithm of analyst following of 0.13 . Given that the firms in my sample are covered by 3.22 analysts in the pre-period, 
this effect translates to an increase of 0.44 analysts, a relative increase in analyst coverage of about $14 \%$, suggesting that the effect is economically significant.

I further replace Number Analysts with Forecasts per Analyst and repeat the estimation. Forecasts per Analyst is the number of earnings forecasts of the firm per analyst in a given year. Column 2 shows the regression results. As predicted, the interaction term between Improved and Post loads significantly, implying that aligning with the predominant FYE is associated with receiving more earnings forecast per analyst. Firms receive 0.21 more earnings forecast per analyst after aligning FYE with their peers. Given that the average number of total earnings forecasts received by the firms in the pre-period is 1.75 per analyst, this effect leads to a $12 \%$ increase. Unlike firms with enhanced comparability, I find no evidence suggesting any change in the total number of analyst earnings forecasts is associated with firms deviating from the predominant FYE in its industry. The evidence, taken together, implies that firms improve their information environment by aligning with peers' FYEs.

I then analyze whether FYE alignment attracts more institutional investors. Institutional investors are important consumers of financial information. Increased uniformity in FYE lowers the costs of acquiring information and thus, attracts more institutional investors (DeFond et al., 2011). I adopt the following OLS regression to test this hypothesis:

$$
\begin{array}{ll}
\text { Institutional Ownership }= & \beta_{0}+\beta_{1} \text { Improved }+\beta_{2} \text { Improved } \times \text { Post }+\beta_{3} \text { Worsened } \\
& +\beta_{4} \text { Worsened } \times \text { Post }+\beta_{5} \text { Post }+\beta_{6} \text { Size } \\
& +\beta_{7} \text { N Analyst }+\beta_{8} \text { Big } 4+\beta_{9} R O E+\beta_{10} \text { Dividend Yield } \\
& +\beta_{11} \text { E/P }+\beta_{12} \text { Cash }+ \text { Industry FE }+ \text { Year FE }+\varepsilon
\end{array}
$$

Institutional Ownership is the percentage of shares held by institutional investors retrieved from Thomson Reuters. Following DeFond et al. (2011) and Fang et al. (2014), I control for firm 
characteristics that are shown to be related to institutional ownership. $N$ Analyst is the number of analysts covering the firm. Big 4 is an indicator that equals one if the firm's auditor is Big Four. $R O E$ is the return on equity ratio. Dividend Yield is total dividends divided by market capitalization. $E / P$ is the earnings to price ratio.

Similar to the analyst coverage analysis, I match each treatment firm with a control industry peer of the closest size, profitability in the previous year and further require non-missing data for the five years surrounding the FYE change.

Table 7 reports the result. The variable of interest is the interaction term between Improved and Post, which captures the extent to which the percentage of institutional ownership changes following the FYE alignment. The coefficient of the interaction term is positive and statistically significant, suggesting that FYE alignment is associated with a significant increase in insititutional ownership. It indicates that institutional ownership increases by $3.7 \%$ in the post period. Given that the average institutional ownership for FYE alignment firms is $9.0 \%$ before the switch, it represents a $41 \%$ increase, suggesting that the magnitude is of economic significance. Moreover, the interaction term between Worsened and Post is negative and statistically significant. The institutional ownership decreases by $4.6 \%$ subsequent to deviation from peers' FYE. Considering the average institutional ownership for such firms in the pre period is $9.9 \%$, this effect translates into a $46 \%$ decrease. The evidence shows that FYE alignment attracts institutional investors.

\subsection{Dumping Losses in Stub Period}

The stub period is the partial year induced by FYE changes. Du and Zhang (2013) find that firms tend to report lower income for the stub period than for adjacent quarters. Their findings indicate that firms may dump losses to the stub period strategically. As firms with losses in the previous year have stronger incentives to discourage investors and other stakeholders to detect 
future losses and reconcile with the previous year's performance, they may be more likely to dump losses in the stub period compared with other firms.

To test this idea, I restrict my sample to non-quarterly FYE shifts as firms' financial results are relatively easy to reconstruct if they are shifting FYEs three, six, or nine months apart. For example, among all the March-end FYE changers, I focus on those switched to new FYEs other than June, September, and December. I then hand collect stub period financial data from EDGAR. This step leaves me with 194 stub period operating results. I employ the following logit estimation to investigate whether loss-making firms are more likely to dump losses to transition period:

$$
\begin{aligned}
\text { Transition Loss } t= & \beta_{0}+\beta_{1} \text { Loss }_{t-1}+\beta_{2} \text { Size }_{t-1}+\beta_{3} \text { ROA }_{t-1}+\beta_{4} \text { Firm Age }_{t-1} \\
& +\beta_{4} \text { Leverage }_{t-1}+\varepsilon
\end{aligned}
$$

where Transition Loss is an indicator variable that equals one if firm $i$ incurs a loss during the stub period, zero otherwise. I include $R O A$ to control for past performance. Leverage is included as the creditors may demand more information disclosure during the stub period when a firm employs more leverage.

Table 8 Panel A reports the descriptive statistics for poor performance and transition loss. Consistent with Du and Zhang (2013), firms tend to report lower earnings during the stub period. On average, 133 out of 194 firms report losses during the stub period. Among these firms with stub period losses, 88 firms incur losses during the previous year while only 18 loss-making firms report positive earnings for the stub period.

Panel B reports the results of estimating Equation (3). The Loss coefficient is positive and statistically significant. The positive coefficient suggests that the probability of reporting a loss during the stub period balloons to $79 \%$ for firms previous losses compared with $58 \%$ for firms without losses. It further supports that loss-making firms are more likely to dump losses to the stub 
period compared with other firms. The results, taken together, suggest that FYE switch decision made by loss firms is at least partially driven by strategic reasons. ${ }^{16}$

\subsection{Audit Fees Analysis}

H3 predicts that small firms are more likely to deviate from a December year-end for accounting cost considerations. Therefore, we should expect salient accounting cost reductions in small firms after deviating from a December year-end. Since data on accounting costs such as employee overtime payment and staff retention costs are not readily available, my analysis will focus on audit fees. Audit fees, as an essential accounting cost, should be expected to decrease as well. To test whether small firms experience audit fee reduction when they switch away from December year-end, I employ the following estimation:

$$
\begin{aligned}
\text { Audit Fees }= & \beta_{0}+\beta_{1} \text { From Dec }+\beta_{2} \text { From Dec } \times \text { Post }+\beta_{3} \text { To Dec } \\
& +\beta_{4} \text { To Dec } \times \text { Post }+\beta_{5} \text { Post }+\beta_{6} \text { Size }+\beta_{7} \text { CR }+\beta_{8} \text { CA_TA } \\
& +\beta_{9} \text { Leverage }+\beta_{10} \text { Arinv }+\beta_{11} \text { Foreign }+\beta_{12} \text { Intangible } \\
& +\beta_{13} \text { Loss }+ \text { FE }+\varepsilon
\end{aligned}
$$

Audit Fees is the natural logarithm of audit fees retrieved from Audit Analytics. Treat is or To Dec.

From Dec is an indicator variable that equals one if firm $i$ changes from a December year-end to a non-December FYE, zero otherwise. To Dec is an indicator variable that equals one if firm $i$ changes from a non-December FYE to a December year-end, zero otherwise.

Following prior literature (Simon and Francis, 1988; Rubin, 1988; Choi et al., 2009; Blankley et al. 2012; Dao et al., 2012), I control for factors documented to have significant

\footnotetext{
${ }^{16}$ In untabulated results, I investigate the relationship between quarterly FYE shifts and stub period losses. I find that $57 \%$ of the quarterly FYE changers report losses during the stub period while $69 \%$ of non-quarterly FYE changers report losses during the stub period. Stub period losses are significantly associated with non-quarterly shifts, but not associated with quarterly shifts. It is possible that firms incur losses and then decide to shift FYEs non-quarterly. It is also possible that firms decide to shift FYEs non-quarterly and then move losses to the stub period. I do not distinguish between the two explanations, but both explanations are consistent with firms' strategic FYE change decisions.
} 
influences on audit fees. $C R, C A_{-} T A$, and Leverage control for firm financial conditions. $C R$ is calculated as total current assets divided by total current liabilities. $C A \_T A$ is the ratio of total current assets divided by total assets. Leverage is the ratio of total liabilities to total assets. Arinv, Foreign and Intangible are proxies for firm complexity. Arinv is the sum of receivables and investment divided by total assets. Foreign is an indicator variable that equals one if firm $i$ has foreign income, zero otherwise. Intangible is the ratio of total intangible assets to total assets. Loss controls for firm's operating results.

As audit fees are concave in firm size (Simunic, 1980; Abbott et al., 2003), small firms should experience more salient audit fee reductions after switching away from a December yearend. To test this, I limit the sample to firms with total assets below the industry median. I further require treatment firms (firms that change FYEs) to have non-missing data for at least two years prior to, the year of, and at least two years following the FYE change.

Table 9 Panel A provides descriptive statistics for the pre and post period after firms change away and to a December FYE. The average audit fees for small firms with a December FYE is $\$ 677,564$ while the average audit fees for small firms with a non-December FYE is $\$ 382,599$.

Panel B reports the regression results of estimating Equation (4). If small firms experience reductions in audit fees, we should expect the coefficient of the interaction term to be negative. Consistent with the prediction, the interaction term is negative and statistically significant. This result indicates that, on average, small firms pay lower audit fees after deviating from a December year-end. After the FYE changes, small firms experience a decrease in the logarithm of audit fees of 0.31. Given that the average audit fees for small December firms before the FYE change in my sample are $\$ 677,564$, this fee reduction effect translates to a decrease of $27 \%$. The magnitude suggests the effect is economically significant. 
Prior literature (e.g., Rubin, 1988; Blankley et al., 2012) document that auditors charge higher fees for firms with December year-end, thus when small firms change to December yearend, higher audit fees should be expected. The interaction term of To Dec and Post is positive and statistically significant. The positive coefficient shows that small firms pay higher audit fees following the alignment of fiscal year-end with calendar year-end. This result indicates that small firms pay roughly $31 \%$ higher for audit fees after changing FYE to a December year-end, given the average audit fee for small non-December firms in the pre-period is $\$ 382,599$.

\section{Conclusion}

In this study, I investigate the reasons that motivate firms to change FYEs, the market reaction to, and the consequences of such changes. My evidence suggests that firms change FYEs to improve the imformation environment by aligning with the predominant FYE adopted by the majority of their peers. Consistent with prior literature, aligning with the predominant FYE among industry peers, a form of comparability, is associated with a significant increase in analyst coverage, forecasts per analyst, and insititional ownership. Further, poorly performing firms are also more likely to change FYEs, ostensibly to dump losses in the stub period. The fact that majority of firms end their fiscal year in December leads to higher explicit and implicit accounting costs at the calendar year-end. Small December year-end firms have limited resources and thus, switch away from December to save accounting costs. In line with accounting cost considerations, small firms that deviate from a December year-end enjoy lower audit fees following the FYE change while those that align FYEs with December experience an increase in audit fees. 


\section{References}

Abbott, L.J., Parker, S., Peters, G.F., Raghunandan, K., 2003. An empirical investigation of audit fees, nonaudit fees, and audit committees. Contemporary Accounting Research, 20, 215- 234.

Antle, R., Gordon, E., Narayanamoorthy, G., and Zhou, L., 2006. The joint determination of audit fees, non-audit fees, and abnormal accruals. Review of Quantitative Finance and Accounting, 27. 235266.

Ball, R.J., 1972. Changes in accounting techniques and stock prices. Journal of Accounting, 10, 1-38.

Ball, R.J., and Brown, P., 1968. An empirical evaluation of accounting income numbers. Journal of Accounting Research, 6, 159-178.

Ball, R.J., and Watts, R., 1972. Some time series properties of accounting income. Journal of Finance, 663682.

Barth, M., Kaznick, R., and McNichols, M.F., 2001. Analyst Coverage and Intangible Assets. Journal of Accounting Research, 39, 1-34.

Barth, M., Landsman,W., Lang, M.,Williams, C., 2012. Are IFRS-based and US GAAP-based accounting amounts comparable? Journal of Accounting and Economics, 54, 68-93.

Bartov, E., Givoly, D., and Hayn, C., 2002. The rewards to meeting or beating earnings expectations. Journal of Accounting and Economics, 33, 173-204.

Bens, D.A., Nagar, V., Skinner, D.J., and Wong M.H.F., 2003. Employee stock options, EPS dilution, and stock repurchases. Journal of Accounting and Economics, 36, 51-90.

Blankley, A.I., Hurtt, D.N., MacGregor, J.E., 2012. Abnormal audit fees and restatements. Auditing: A Journal of Practice \& Theory, 31, 79-96.

Bhushan, R., 1989. Firm Characteristics and Analyst Following. Journal of Accounting and Economics, 11, $255-274$.

Brennan, M., and Hughes, P. 1991. Stock Prices and the Supply of Information. The Journal of Finance, 46, 1665-91.

Boynton, C.E., Dobbins, P.S., Plesko, G.A., 1992. Earnings management and the corporate alternative minimum tax. Journal of Accounting Research, 30, 131-153.

Choi, J., Kim, J., Liu, X. and Simunic., D.A., 2009. Cross-listing audit fee premium: Theory and evidence. The Accounting Review, 84, 1429-1463.

Code of Federal Regulations. 17 CFR $§ 240.15 d-10$.

Dao, M., Raghunandan, K. and Rama., D.V. 2012. Shareholder voting on auditor selection, audit fees, and audit quality. The Accounting Review, 87, 149-171.

DeAngelo, H., DeAngelo, L., and Skinner, D.J., 1994. Accounting choice in troubled companies. Journal of Accounting and Economics, 17, 113-143.

DeFond, M., Hu, X., Hung, M., Li, S., 2011. The impact of mandatory IFRS adoption on foreign mutual fund ownership: The role of comparability. Journal of Accounting and Economics, 51, 240-258.

DeFond, M.L. and Park, C.W., 1997. Smoothing income in anticipation of future earnings. Journal of Accounting and Economics, 23, 115-139. 
De Franco, G., Kothari, S.P., Verdi, R.S., 2001. The benefits of financial statement comparability. Journal of Accounting Research,49, 895-931.

De Franco, G., Vasvari, F.P., and Wittenberg-moerman, R., 2009. The informational role of bond analysts. Journal of Accounting Research, 47, 1201-1248.

Dhaliwal, D., Wang, S., 1992. The effect of book income adjustment in the 1986 alternative minimum tax on corporate financial reporting. Journal of Accounting and Economics, 15, 726.

Du, K., and Zhang, X.F., 2013. Orphans deserve attention: financial reporting in the missing months when corporations change fiscal year. The Accounting Review, 88, 945-975.

Dye, R.A., Verrecchia, R.E., 1995. Discretion vs. uniformity: choices among GAAP. The Accounting Review, 70, 389-415.

Erickson, M., and Wang, S., 1999. Earnings management by acquiring firms in stock for stock mergers. Journal of Accounting and Economics, 27, 149-176.

Evans, J., and Sridhar, S., 1996. Multiple control systems, accrual accounting, and earnings management. Journal of Accounting Research, 34, 45-65.

Exchange Act Rule 13a-10.

Exchange Act Rule 15d-13.

Exempt Organizations Annual Reporting Requirements. Exempt Organizations Annual Reporting Requirements - Filing Procedures: Change in Accounting Period. Retrieved from https://www.irs.gov/charities-non-profits/exempt-organizations-annual-reporting-

requirementsfiling-procedures-change-in-accounting-period.

Fama E.F., and Babiak, H., 1968. Dividend policy: An empirical analysis. Journal of the American Statistical Association, 1132-1161.

Fang, V.W., Maffett, M., Zhang, B., 2014. Foreign institutional ownership and the global convergence of financial reporting practices. Journal of Accounting Research, 53, 593-631.

Financial Accounting Standards Board (FASB), 1980. Qualitative characteristics of accounting information. Concepts statement No. 2. Norwalk, CT: FASB.

Fields, T.D., Lys, T.Z., Vincent, L., 2001. Empirical research on accounting choice. Journal of Accounting and Economics, 31, 255-301.

Foster, G., 1986. Financial statement analysis, second ed. Prentice-Hall, Englewood Cliffs, NJ. Francis, J. R., and D. Wang. 2005. Impact of the SECs public fee disclosure requirement on subsequent period fees and implications for market efficiency. Auditing: A Journal of Practice \& Theory 24 (Supplement): 145-160.

FRC 102.05. Codification of Financial Reporting Policies.

Goldman Sachs Group, Inc, 2009. Annual report. Retrieved from https://www.sec.gov/Arch ives/edgar/data/886982/000095012310018464/y81914e10vk.htm.

Guenther, D.A., 1994. Earnings management in response to corporate tax rate changes: evidence from the 1986 tax reform act. The Accounting Review, 69, 230-243.

Guidry, F., Leone, A.J., Rock, S., 1999. Earnings-based bonus plans and earnings management by businessunit managers. Journal of Accounting and Economics, 26, 113-142. 
Healy, P., 1985. The impact of bonus schemes on the selection of accounting principles. Journal of Accounting and Economics, 7, 85-107.

Healy, P., and Palepu, K., 1990. Effectiveness of accounting-based dividend covenants. Journal of Accounting and Economics, 12, 97-123.

Hiscock, K., "Feature article: Accounting issues for investors - An occasional series - Part 1," June 2, 2015, available from Thomson One, accessed May 15, 2018.

Holthausen, R., Leftwich, R., 1983. The economic consequences of accounting choice: implications of costly contracting and monitoring. Journal of Accounting and Economics 5, 77-117. Huberman, G., and Kandel, S., 1989. Firms fiscal years, sizes and industry. Economics Letters, 29. 69-75.

Huang, H, Raghunandan, K., and Rama, D., 2009. Audit fees for initial audit engagements before and after SOX. Auditing: A Journal of Practice \& Theory 28 (1): 171-190.

Kamp, B., 2002. Fiscal year-end choice: determinants and dynamics. The International Journal of Accounting, 37, 421-427.

Kaplan, R.S., and Roll, R., 1972. Investor evaluation of accounting information: Some empirical evidence. Journal of Business, 45, 225-257.

Kim, M., and Kross,W., 1998. The impact of the 1989 change in bank capital standards on loan loss provisions and loan write-offs. Journal of Accounting and Economics, 25, 69-99.

Kothari, S.P., Shu, S., Wysocki, P.D., 2009. Do managers withhold bad news? Journal of Accounting Research, 47, 241-276.

Kimmel, P.D., Weygandt, J.J., and Kieso, D.E., 2015. Financial Accounting. John Wiley \& Sons, Hoboken, NJ.

Lang, M.H., and Lundholm, R.J., 1996. Corporate Disclosure Policy and Analyst Behavior. The Accounting Review, 71, 467-492.

Li, S., 2010. Does Mandatory Adoption of International Financial Reporting Standards in the European Union Reduce the Cost of Equity Capital? The Accounting Review, 85, 607-636.

McCosh, A.M., 1967. Accounting consistency - key to stockholder information. The Accounting Review, 42, 693-700.

Moyer, S.E., 1990. Capital adequacy ratio regulations and accounting choices in commercial banks. Journal of Accounting and Economics, 13, 123-154.

O'Brien, P., and Bhushan, R., 1990. Analyst Following and Institutional Ownership. Journal of Accounting Research Supplement, 28, 55-76.

Pandora Media Inc., 2013. Annual report. Retrieved from https://www.sec.gov/Archives/edgar/ data/1230276/000104746914000909/a2218261z10-kt.htm.

Peterson, K., Schmardebeck, R., Wilks, T., 2015. The earnings quality and information processing effects of accounting consistency. The Accounting Review, 90, 2483-2514.

Petroni, K.R., 1992. Optimistic reporting in the property casualty insurance industry. Journal of Accounting and Economics, 15, 485-508.

Perry, S.E., Williams, T.H., 1994. Earnings management preceding management buyout offers. Journal of Accounting and Economics, 18, 157-179. 
Rare Element Resources Ltd, 2013. Annual reports. Retrieved from https://www.sec.gov/ Archives/edgar/data/1419806/000105291813000084/ree10ktransmar1813ev8.htm.

Roychowdhury, S., 2006. Earnings management through real activities manipulation. Journal of Accounting and Economics, 42, 335-370.

Rubin, M.A., 1988. Municipal audit fee determinants. The Accounting Review, 63, 219-236.

Simons, D.T., and Francis, J.R., 1988. The effects of auditor change on audit fees: Tests of price cutting and price recovery. The Accounting Review, 63, 255-269.

Simunic, D.A., 1980. The pricing of audit services: theory and evidence. Journal of Accounting Research, $18,161-190$.

Smith, C.W., and Warner, J.B., 1979. On financial contracting: an analysis of bond covenants. Journal of Financial Economic, 7, 117-162.

Smith, D.B., and Pourciau, S., 1988. A comparison of the financial characteristics of December and nonDecember year-end companies. Journal of Accounting and Economics, 10, 335-344.

Sunder, S., 1973. Relationship between accounting changes and stock prices: Problems of measurement and some empirical evidence. Journal of Accounting Research, 11, 1-45.

Sweeney, A.P., 1994. Debt-covenant violations and managers accounting responses. Journal of Accounting and Economics, 17, 281-308.

Synergy Resources Corporation, 2016. Annual report. Retrived from https :// www.sec.gov/Archives/edgar/data/1413507/000141350716000126/a10-ktsyrg20151231. htm.

Tan, H., Wang, S., and Welker, M., 2011. Accuracy After Mandated IFRS Adoptions. Journal of Accounting Research, 49, 1307-1357.

Tecnoglass Inc.,2013. Annual report. Retrieved from https:/www.sec.gov/Archives/ edgar/data/1534675/000114420414023048/v37419510k.htm.

Watts, R.L., Leftwich R.W., 1978. The time series of annual accounting earnings. Journal of Accounting Research, 15, 253-271.

Watts, R.L., Zimmerman, J.L., 1978. Towards a positive theory of the determination of accounting standards. The Accounting Review, 53, 112-134.

Watts, R.L., Zimmerman, J.L., 1986. Positive Accounting Theory. Prentice-Hall, Englewood Cliffs, NJ.

Young, S., Zeng, Y., 2015. Accounting comparability and the accuracy of peer-based valuation models. The Accounting Review, 90, 2571-2601. 


\section{Appendix A: Variable definitions}

\begin{tabular}{|c|c|}
\hline Variable Name & Definition \\
\hline$\triangle F Y E$ & Indicator variable that equals 1 if firm $i$ changes FYE in year $t, 0$ otherwise. \\
\hline$\Delta$ Segment & $\begin{array}{l}\text { Indicator variable that equals } 1 \text { if firm } i \text { has at least } 1 \text { new business segment, } 0 \\
\text { otherwise. }\end{array}$ \\
\hline Absolute Return & Absolute value of daily return. \\
\hline Arinv & Sum of receivables and inventory divided by total assets. \\
\hline Audit Fees & Natural logarithm of audit fees \\
\hline Big 4 & Indicator variable that equals 1 if firm $i$ 's auditor is Big Four. \\
\hline Book to Market & Ratio of the book value to the market value of equity. \\
\hline$C A_{-} T A$ & Current assets divided by total assets. \\
\hline Cash & Cash and cash equivalents divided by total assets. \\
\hline$C R$ & Current ratio, calculated as total current assets divided by total current liabilities. \\
\hline Depreciation & $\begin{array}{l}\text { Depreciation expense divided by total sales, less the respective two-digit SIC } \\
\text { industry mean value of depreciation expense divided by total sales. }\end{array}$ \\
\hline Difference & Difference between Event and Nonevent. \\
\hline Dividend Yield & Total dividend divided by market capitalization. \\
\hline$E / P$ & Earnings to price ratio, calculated as net income divided by price. \\
\hline Event & Daily average during -1 to +1 event window. \\
\hline Firm Age & Natural logarithm of the number of years since the firm first appears in Compustat. \\
\hline Forecast per Analyst & Number of total analyst' earnings forecasts of the firm. \\
\hline Foreign & Indicator variable that equals 1 if firm $i$ has foreign income, 0 otherwise. \\
\hline From Dec & $\begin{array}{l}\text { Indicator variable that equals } 1 \text { if firm i changed from December FYE to a non- } \\
\text { December FYE, } 0 \text { otherwise. }\end{array}$ \\
\hline Improved & $\begin{array}{l}\text { Indicator variable that equals to } 1 \text { if firm i changed from non-predominant FYE to } \\
\text { predominant FYE, } 0 \text { otherwise. }\end{array}$ \\
\hline Intangible & Intangible assets divided by total assets. \\
\hline Leverage & Total liabilities divided by total assets. \\
\hline
\end{tabular}


Loss

$M \& A$

Non Dec

$N$ Analyst

Number Analyst

Nonevent

Non Predominant

Post

Return

$R O A$

$R O E$

$R \& D$

Size

To Dec

Trading Volume

Transition Loss

Volatility Earning

Volatility Return

Volume

Worsened
Indicator variable that equals to 1 if net income of firm $i$ in year $t$ is negative, 0 otherwise.

Indicator variable that equals to 1 if firm $\mathrm{i}$ is involved in an M\&A activities, 0 otherwise.

Indicator variable that equals 1 if firm i changed from a non-December FYE to another non-December FYE, 0 otherwise.

The number of analysts issuing a earnings forecast for the firm.

Logarithm of 1 plus the number of analysts issuing a earnings forecast for the firm.

Daily average during -30 to -2 and +2 to +30 event window.

Indicator variable that equals to 1 if current FYE is not the predominant FYE adopted by its peers, 0 otherwise.

Indicator variable that equals to 1 if the year is after the year of FYE change, 0 otherwise.

Daily raw return.

Return on assets ratio, calculated as earnings before extraordinary items devided by average total assets.

Return on equity ratio, calculated as earnings before extraordinary items devided by total equity.

Research and development expense devided by total sales, less the respective twodigit SIC industry mean value of research and development expense divided by total sales.

Natural logarithm of total assets of firm $\mathrm{i}$ in year $\mathrm{t}$.

Indicator variable that equals 1 if firm $i$ changed FYE from a non-December FYE to a December FYE, 0 otherwise.

Daily trading volume scaled by number of shares outstanding

Indicator variable that equals 1 if firm i reports a loss during the transition period, 0 otherwise.

Standard deviation of 16 quarterly earnings.

Standard deviation of 48 months of stock returns.

Logarithm of trading volume in millions of shares during the year.

Indicator variable that equals to 1 if firm i changed from predominant FYE to nonpredominant FYE, 0 otherwise. 


\section{Table 1: Summary statistics}

Panel A: FYE month distribution

This panel displays the FYE breakdown by calendar month in the sample.

\begin{tabular}{lrc}
\hline FYE Month & Freq & $\%$ \\
\hline January & 8,223 & $3.9 \%$ \\
February & 3,626 & $1.7 \%$ \\
March & 13,014 & $6.1 \%$ \\
April & 4,384 & $2.1 \%$ \\
May & 4,266 & $2.0 \%$ \\
June & 17,812 & $8.4 \%$ \\
July & 4,205 & $2.0 \%$ \\
August & 4,258 & $2.0 \%$ \\
September & 14,327 & $6.7 \%$ \\
October & 5,509 & $2.6 \%$ \\
November & 2,942 & $1.4 \%$ \\
December & 130,216 & $61.2 \%$ \\
Total & 212,782 & $100 \%$ \\
\hline
\end{tabular}


Panel B: FYE change matrix

This panel provides the matrix with total number of FYE changes made from one calendar month to another.

\begin{tabular}{|c|c|c|c|c|c|c|c|c|c|c|c|c|c|c|c|}
\hline & & \multicolumn{12}{|c|}{ From the month of } & \multirow[b]{2}{*}{ Total } & \multirow[b]{2}{*}{$\%$} \\
\hline & & Jan & Feb & Mar & Apr & May & Jun & $\mathrm{Jul}$ & Aug & Sept & Oct & Nov & Dec & & \\
\hline \multirow{14}{*}{$\begin{array}{l}\text { To the } \\
\text { month } \\
\text { of }\end{array}$} & Jan & 0 & 6 & 3 & 10 & 4 & 15 & 16 & 3 & 4 & 7 & 2 & 54 & 124 & $5.7 \%$ \\
\hline & Feb & 0 & 0 & 4 & 2 & 8 & 4 & 4 & 2 & 4 & 0 & 2 & 6 & 36 & $1.7 \%$ \\
\hline & Mar & 4 & 7 & 0 & 9 & 6 & 23 & 8 & 4 & 19 & 9 & 4 & 74 & 167 & $7.7 \%$ \\
\hline & Apr & 6 & 0 & 7 & 0 & 1 & 5 & 1 & 2 & 3 & 1 & 0 & 17 & 43 & $2.0 \%$ \\
\hline & May & 0 & 1 & 3 & 2 & 0 & 3 & 0 & 2 & 3 & 2 & 2 & 15 & 33 & $1.5 \%$ \\
\hline & Jun & 9 & 5 & 18 & 9 & 11 & 0 & 14 & 12 & 20 & 7 & 2 & 100 & 207 & $9.6 \%$ \\
\hline & Jul & 5 & 1 & 4 & 3 & 0 & 3 & 0 & 2 & 3 & 0 & 1 & 8 & 30 & $1.4 \%$ \\
\hline & Aug & 1 & 0 & 3 & 0 & 2 & 3 & 0 & 0 & 4 & 1 & 2 & 14 & 30 & $1.4 \%$ \\
\hline & Sept & 6 & 5 & 8 & 3 & 4 & 16 & 2 & 15 & 0 & 9 & 6 & 103 & 177 & $8.2 \%$ \\
\hline & Oct & 5 & 3 & 0 & 1 & 0 & 4 & 2 & 0 & 4 & 0 & 1 & 20 & 40 & $1.8 \%$ \\
\hline & Nov & 0 & 3 & 2 & 0 & 4 & 2 & 0 & 4 & 1 & 2 & 0 & 6 & 24 & $1.1 \%$ \\
\hline & Dec & 77 & 64 & 225 & 70 & 77 & 271 & 62 & 78 & 201 & 67 & 60 & 0 & 1,252 & $57.9 \%$ \\
\hline & Total & 113 & 95 & 277 & 109 & 117 & 349 & 109 & 124 & 266 & 105 & 82 & 417 & 2,163 & \\
\hline & $\%$ & $5.2 \%$ & $4.4 \%$ & $12.8 \%$ & $5.0 \%$ & $5.4 \%$ & $16.1 \%$ & $5.0 \%$ & $5.7 \%$ & $12.3 \%$ & $4.9 \%$ & $3.8 \%$ & $19.3 \%$ & & \\
\hline
\end{tabular}


Panel C: FYE change by year

This panel provides the descriptive statistics of the FYE change breakdown by year and by types. Three types of changes are identified, changes from a December FYE, changes to a December FYE and changes from a non-December FYE to another non-December FYE.

\begin{tabular}{|c|c|c|c|c|c|c|}
\hline Year & Total Obs & Change from Dec & Change to Dec & $\begin{array}{l}\text { Non-Dec to } \\
\text { Non-Dec }\end{array}$ & $\begin{array}{r}\text { Total } \\
\text { Change }\end{array}$ & $\%$ \\
\hline 1980 & 4,634 & 9 & 19 & 8 & 36 & $0.8 \%$ \\
\hline 1981 & 4,564 & 11 & 24 & 8 & 43 & $0.9 \%$ \\
\hline 1982 & 4,603 & 3 & 17 & 9 & 29 & $0.6 \%$ \\
\hline 1983 & 4,651 & 6 & 23 & 21 & 50 & $1.1 \%$ \\
\hline 1984 & 4,809 & 5 & 25 & 20 & 50 & $1.0 \%$ \\
\hline 1985 & 4,901 & 17 & 28 & 10 & 55 & $1.1 \%$ \\
\hline 1986 & 4,967 & 11 & 35 & 23 & 69 & $1.4 \%$ \\
\hline 1987 & 5,299 & 27 & 39 & 16 & 82 & $1.5 \%$ \\
\hline 1988 & 5,573 & 15 & 39 & 39 & 93 & $1.7 \%$ \\
\hline 1989 & 5,588 & 12 & 38 & 23 & 73 & $1.3 \%$ \\
\hline 1990 & 5,535 & 14 & 45 & 23 & 82 & $1.5 \%$ \\
\hline 1991 & 5,537 & 12 & 44 & 18 & 74 & $1.3 \%$ \\
\hline 1992 & 5,618 & 17 & 35 & 13 & 65 & $1.2 \%$ \\
\hline 1993 & 5,842 & 11 & 48 & 17 & 76 & $1.3 \%$ \\
\hline 1994 & 6,143 & 12 & 46 & 23 & 81 & $1.3 \%$ \\
\hline 1995 & 6,369 & 27 & 41 & 11 & 79 & $1.2 \%$ \\
\hline 1996 & 6,666 & 16 & 64 & 25 & 105 & $1.6 \%$ \\
\hline 1997 & 7,386 & 10 & 69 & 33 & 112 & $1.5 \%$ \\
\hline 1998 & 7,426 & 16 & 75 & 24 & 115 & $1.5 \%$ \\
\hline 1999 & 7,055 & 18 & 58 & 14 & 90 & $1.3 \%$ \\
\hline 2000 & 6,980 & 13 & 63 & 12 & 88 & $1.3 \%$ \\
\hline 2001 & 6,737 & 15 & 51 & 12 & 78 & $1.2 \%$ \\
\hline 2002 & 6,514 & 16 & 52 & 16 & 84 & $1.3 \%$ \\
\hline 2003 & 6,207 & 18 & 30 & 13 & 61 & $1.0 \%$ \\
\hline 2004 & 6,036 & 19 & 23 & 7 & 49 & $0.8 \%$ \\
\hline 2005 & 5,857 & 5 & 23 & 7 & 35 & $0.6 \%$ \\
\hline 2006 & 5,609 & 12 & 31 & 6 & 49 & $0.9 \%$ \\
\hline 2007 & 5,340 & 15 & 15 & 4 & 34 & $0.6 \%$ \\
\hline 2008 & 5,059 & 4 & 13 & 7 & 24 & $0.5 \%$ \\
\hline 2009 & 4,876 & 5 & 6 & 5 & 16 & $0.3 \%$ \\
\hline 2010 & 4,744 & 3 & 17 & 4 & 24 & $0.5 \%$ \\
\hline 2011 & 4,538 & 4 & 21 & 5 & 30 & $0.7 \%$ \\
\hline 2012 & 4,473 & 2 & 14 & 2 & 18 & $0.4 \%$ \\
\hline 2013 & 4,531 & 3 & 19 & 1 & 23 & $0.5 \%$ \\
\hline 2014 & 4,702 & 3 & 8 & 2 & 13 & $0.3 \%$ \\
\hline 2015 & 4,642 & 6 & 18 & 5 & 29 & $0.6 \%$ \\
\hline 2016 & 4,422 & 3 & 19 & 3 & 25 & $0.6 \%$ \\
\hline 2017 & 4,251 & 0 & 11 & 4 & 15 & $0.4 \%$ \\
\hline 2018 & 4,098 & 2 & 6 & 1 & 9 & $0.2 \%$ \\
\hline Total & 212,782 & 417 & 1,252 & 494 & 2,163 & $1.0 \%$ \\
\hline
\end{tabular}


Panal D: Predominant FYE distribution

This panel shows the predominant FYE distribution. Predominant FYE is defined as the month adopted by the most number of firms in industry $j$ in yeat $t$.

\begin{tabular}{lrc}
\hline Month & Freq & $\%$ \\
\hline January & 7 & $8.05 \%$ \\
March & 1 & $1.15 \%$ \\
April & 1 & $1.15 \%$ \\
May & 3 & $3.45 \%$ \\
June & 7 & $8.05 \%$ \\
July & 1 & $1.15 \%$ \\
August & 1 & $1.15 \%$ \\
September & 3 & $3.45 \%$ \\
October & 2 & $2.30 \%$ \\
November & 2 & $2.30 \%$ \\
December & 59 & $67.82 \%$ \\
Total & 87 & $100 \%$ \\
\hline
\end{tabular}

Panel E: FYE change matrix

This panel shows the change matrix based on industry predominant FYE. Predominant FYE is defined as the month adopted by the most number of firms in industry $j$ in yeat $t$. Non-predominant FYE is defined as the FYE that differ predominant FYE in an industry in a given year.

\begin{tabular}{llrrr}
\hline & & \multicolumn{2}{c}{ From } & \\
\cline { 3 - 4 } & & Non-predominant FYE & Predominant FYE & \multicolumn{2}{c}{ Total } \\
\hline To & Non-predominant FYE & 468 & 408 & 876 \\
& Predominant FYE & 1,281 & 6 & 1,287 \\
& Total & 1,749 & 414 & 2,163 \\
\hline
\end{tabular}




\section{Table 2: Logit regression results - full sample}

This table reports the logit results of Equation (1). The results are based on all firm-year observations in the sample. Test statistics (two-sided) based on robust standard errors clustered at the year and industry level are reported in parenthesis. ***, **, and * indicate statistical significance at the $1 \%, 5 \%$, and $10 \%$ level, respectively.

\begin{tabular}{lc}
\hline & $\Delta F Y E$ \\
\hline Non Predominant & $1.94 * * *$ \\
Loss & $(10.96)$ \\
Size & $0.50^{* * *}$ \\
& $(8.00)$ \\
M\&A & -0.02 \\
& $(-1.18)$ \\
Segment & $0.35^{* * *}$ \\
& $(4.35)$ \\
Foreign & $0.25^{* * *}$ \\
& $(3.88)$ \\
Firm Age & 0.05 \\
& $(1.04)$ \\
Observations & $-0.30^{* * *}$ \\
Industry FE & $(-9.74)$ \\
Year FE & \\
Pseudo $R^{2}(\%)$ & 212,782 \\
& Yes \\
& Yes \\
\hline
\end{tabular}




\section{Table 3: Summary of audit fees by firm size}

This table displays the summary statistics of the audit fees as of total assets. Numbers are in percentage except for observation numbers and $t$-statistic.

\begin{tabular}{lrrrrrrr}
\hline & Obs & Mean & $10 \%$ & $25 \%$ & $50 \%$ & $75 \%$ & $90 \%$ \\
\hline Small firms & 39,439 & 0.82 & 0.09 & 0.18 & 0.42 & 0.90 & 1.83 \\
Large firms & 39,492 & 0.14 & 0.02 & 0.04 & 0.09 & 0.18 & 0.32 \\
Diff (small - large) & & $0.68 * * *$ & & & & & \\
$t$-value & & 97.81 & & & & & \\
\hline
\end{tabular}




\section{Table 4: Logit regression results — changes from and to December year-ends}

This table reports the logit results of Equation (1). Column 1 reports the coefficients from regression for FYE changes from December year-ends to non-December year-ends. $\triangle F Y E$ is one if firm $i$ changes from December year-end to non-December year-end in year $t$, zero otherwise. Control groups are firms with December year-end firms. Column 2 lists the coefficients from regression for FYE changes from Non-December year-ends to December year-ends. $\triangle F Y E$ is one if firm $i$ changes from Non-December year-end to December year-end in year $t$, zero otherwise. Control groups are firms with non-December year-end firms. Column 3 reports the reports the coefficients from regression for FYE changes from a non-December year-ends to another non-December year-ends. The dependent variable $\triangle F Y E$ equals one if firm $i$ changes FYE from a non-December year-end to another non-December year-end in year $t$, zero otherwise. The control groups are limited to non-December year-end firm-year firms. Test statistics (two-sided) based on robust standard errors clustered at the year and industry level are reported in parenthesis. ${ }^{* *},{ }^{* *}$, and $*$ indicate statistical significance at the $1 \%, 5 \%$, and $10 \%$ level, respectively.

\begin{tabular}{|c|c|c|c|}
\hline & $\begin{array}{c}\Delta \text { From Dec } \\
(1)\end{array}$ & $\begin{array}{c}\Delta \text { To Dec } \\
\text { (2) }\end{array}$ & $\begin{array}{l}\text { Non-Dec to Non-Dec } \\
\text { (3) }\end{array}$ \\
\hline \multirow[t]{2}{*}{ Non Predominant } & $1.87 * * *$ & $1.22 * * *$ & 0.68 \\
\hline & $(10.53)$ & $(6.26)$ & $(0.47)$ \\
\hline \multirow[t]{2}{*}{ Loss } & $0.47 * * *$ & $0.56 * * *$ & $0.53 * * *$ \\
\hline & $(5.26)$ & $(6.23)$ & $(7.01)$ \\
\hline \multirow[t]{2}{*}{ Size } & $-0.14 * * *$ & 0.04 & -0.03 \\
\hline & $(-5.39)$ & $(1.36)$ & $(-1.17)$ \\
\hline \multirow[t]{2}{*}{$M \& A$} & $0.40 * * *$ & $0.36 * * *$ & 0.25 \\
\hline & $(3.33)$ & $(4.16)$ & $(1.51)$ \\
\hline \multirow[t]{2}{*}{$\Delta$ Segment } & 0.17 & $0.28 * * *$ & 0.25 \\
\hline & $(0.98)$ & $(4.41)$ & $(1.41)$ \\
\hline \multirow[t]{2}{*}{ Foreign } & 0.03 & 0.03 & 0.11 \\
\hline & $(0.19)$ & $(0.35)$ & $(1.15)$ \\
\hline \multirow[t]{2}{*}{ Firm Age } & $-0.18 * * *$ & $-0.37 * * *$ & $-0.19 * * *$ \\
\hline & $(-3.00)$ & $(-9.27)$ & $(-3.85)$ \\
\hline Observations & 122,599 & 85,416 & 71,761 \\
\hline Industry FE & Yes & Yes & Yes \\
\hline Year FE & Yes & Yes & Yes \\
\hline Pseudo $R^{2}(\%)$ & 10.62 & 6.02 & 4.99 \\
\hline
\end{tabular}




\section{Table 5: Event study significance test}

\section{Panel A: Aggregated test}

This panel reports the results of $t$ test for the difference between the event window and nonevent window for Trading Volume, absolute Return, and Return. ${ }^{* *},{ }^{* *}$, and * indicate statistical significance at the $1 \%, 5 \%$, and $10 \%$ level, respectively.

\begin{tabular}{lcrrr}
\hline & Obs & Trading Volume & Absolute Return & \multicolumn{1}{c}{ Return } \\
\hline Event & 265 & $0.69 \%$ & $3.75 \%$ & $0.13 \%$ \\
Nonevent & 265 & $0.60 \%$ & $3.29 \%$ & $-0.12 \%$ \\
Difference & 265 & $0.09 \% *$ & $0.46 \% * * *$ & $0.25 \% *$ \\
-value & & 0.098 & 0.001 & 0.062 \\
\hline
\end{tabular}

\section{Panel B: Signed return test}

This panel reports the results of $t$ test for daily return difference between the average daily return during 3-day event window surrounding the FYE change disclosure and the daily return during the non-event window. ***, **, and * indicate statistical significance at the $1 \%, 5 \%$, and $10 \%$ level, respectively.

\begin{tabular}{lrrr}
\hline Sample & Obs & Mean Difference & $p$-value \\
\hline Full & 265 & $0.25 \%^{*}$ & 0.062 \\
Improved comparability & 177 & $0.28 \%^{*}$ & 0.095 \\
Worsened comparability & 54 & $0.00 \%$ & 0.389 \\
Loss in previous year & 149 & $0.33 \%^{*}$ & 0.083 \\
Profit in previous year & 116 & $0.17 \%$ & 0.238 \\
Small \& From Dec & 32 & $0.00 \%$ & 0.447 \\
Small \& To Dec & 99 & $0.21 \%$ & 0.251 \\
\hline
\end{tabular}




\section{Table 6: Analyst coverage analysis}

This table reports the regression results of analyst coverage analysis. Column 1 examines the effect on Number Analyst. Column 2 investigate the effect on Number Forecast. Test statistics (two-sided) based on robust standard errors clustered at the year and industry level are reported in parenthesis. ${ }^{* *}, * *$, and $*$ indicate statistical significance at the $1 \%, 5 \%$, and $10 \%$ level, respectively.

\begin{tabular}{|c|c|c|}
\hline & $\begin{array}{l}\text { Number Analyst } \\
\text { (1) }\end{array}$ & $\begin{array}{c}\text { Forecast per Analyst } \\
\text { (2) }\end{array}$ \\
\hline Improved & $\begin{array}{c}-0.24 * * * \\
(-3.46)\end{array}$ & $\begin{array}{c}-0.40 * * * \\
(-5.84)\end{array}$ \\
\hline Improved $\times$ Post & $\begin{array}{l}0.13 * * \\
(2.47)\end{array}$ & $\begin{array}{l}0.21 * * \\
(2.04)\end{array}$ \\
\hline Unimproved & $\begin{array}{l}-0.02 \\
(-0.25)\end{array}$ & $\begin{array}{l}-0.15 \\
(-1.41)\end{array}$ \\
\hline Unimproved $\times$ Post & $\begin{array}{c}0.16 \\
(1.15)\end{array}$ & $\begin{array}{l}-0.06 \\
(-0.52)\end{array}$ \\
\hline Post & $\begin{array}{l}-0.01 \\
(-0.37)\end{array}$ & $\begin{array}{c}0.03 \\
(0.47)\end{array}$ \\
\hline Size & $\begin{array}{c}0.24 * * * \\
(9.96)\end{array}$ & $\begin{array}{c}0.30^{* * *} \\
(6.08)\end{array}$ \\
\hline Book to Market & $\begin{array}{c}0.00 \\
(1.03)\end{array}$ & $\begin{array}{c}0.01 * * * \\
(2.82)\end{array}$ \\
\hline$R O A$ & $\begin{array}{c}0.03 \\
(0.35)\end{array}$ & $\begin{array}{l}-0.06 \\
(-0.42)\end{array}$ \\
\hline Depreciation & $\begin{array}{c}-0.00 * * * \\
(-4.58)\end{array}$ & $\begin{array}{c}-0.01 * * * \\
(-3.92)\end{array}$ \\
\hline$R \& D$ & $\begin{array}{c}0.00 * * * \\
(17.28)\end{array}$ & $\begin{array}{c}0.00 * * * \\
(6.20)\end{array}$ \\
\hline Volume & $\begin{array}{c}0.28^{* * * *} \\
(13.11)\end{array}$ & $\begin{array}{c}0.31 * * * \\
(9.34)\end{array}$ \\
\hline Volatility Return & $\begin{array}{c}-2.28 * * * \\
(-7.78)\end{array}$ & $\begin{array}{c}-2.90 * * * \\
(-5.31)\end{array}$ \\
\hline Volatility Earning & $\begin{array}{c}-0.00 * * * \\
(-2.74)\end{array}$ & $\begin{array}{c}-0.00 * * * \\
(-5.73)\end{array}$ \\
\hline $\begin{array}{l}\text { Observations } \\
\text { Industry FE } \\
\text { Year FE } \\
R^{2}(\%)\end{array}$ & $\begin{array}{c}2,310 \\
\text { Yes } \\
\text { Yes } \\
68.70 \\
\end{array}$ & $\begin{array}{c}2,310 \\
\text { Yes } \\
\text { Yes } \\
49.59 \\
\end{array}$ \\
\hline
\end{tabular}




\section{Table 7: Institutional ownership analysis}

This table reports the regression results of analyst coverage analysis. Column 1 examines the effect on Number Analyst. Column 2 investigate the effect on Number Forecast. Test statistics (two-sided) based on robust standard errors clustered at the year and industry level are reported in parenthesis. ${ }^{* *}, * *$, and $*$ indicate statistical significance at the $1 \%, 5 \%$, and $10 \%$ level, respectively.

\begin{tabular}{|c|c|}
\hline & Institutional Ownership \\
\hline Improved & $\begin{array}{c}-0.04 * * * \\
(-6.91)\end{array}$ \\
\hline Improved $\times$ Post & $\begin{array}{c}0.04 * * * \\
(3.66)\end{array}$ \\
\hline Unimproved & $\begin{array}{l}-0.02 * \\
(-1.72)\end{array}$ \\
\hline Unimproved $\times$ Post & $\begin{array}{c}-0.05 * * * \\
(-2.59)\end{array}$ \\
\hline Post & $\begin{array}{l}0.02 * * \\
(2.34)\end{array}$ \\
\hline Size & $\begin{array}{c}0.02 * * * \\
(16.96)\end{array}$ \\
\hline$N$ Analyst & $\begin{array}{c}0.01 * * * \\
(21.33)\end{array}$ \\
\hline Big 4 & $\begin{array}{c}0.03 * * * \\
(5.04)\end{array}$ \\
\hline$R O E$ & $\begin{array}{c}0.00 \\
(0.63)\end{array}$ \\
\hline Dividend Yield & $\begin{array}{l}-0.01 \\
(-1.21)\end{array}$ \\
\hline$E / P$ & $\begin{array}{c}0.00 \\
(0.44)\end{array}$ \\
\hline Cash & $\begin{array}{c}0.04 * * * \\
(3.20)\end{array}$ \\
\hline Observations & 7,920 \\
\hline Industry FE & Yes \\
\hline Year FE & Yes \\
\hline$R^{2}(\%)$ & 27.86 \\
\hline
\end{tabular}




\section{Table 8: Transition period loss dump}

Panel A: Descriptive statistics for poor performance and transition loss

\begin{tabular}{lccc}
\hline & No loss in $t-1$ & Loss in $t-1$ & Total \\
\hline No transition loss & 43 & 18 & 61 \\
Transition loss & 45 & 88 & 133 \\
Total & 88 & 106 & 194 \\
\hline
\end{tabular}

Panel B: Regression results

This panel reports the Equation (4). Test statistics (two-sided) based on robust standard errors are reported in parenthesis. ${ }^{* *},{ }^{* *}$, and $*$ indicate statistical significance at the $1 \%, 5 \%$, and $10 \%$ level, respectively.

\begin{tabular}{lc}
\hline & Transition Loss \\
\hline Loss & $1.13^{* * *}$ \\
Size & $(3.07)$ \\
& $-0.20^{* *}$ \\
ROA & $(-2.01)$ \\
Firm Age & -0.29 \\
& $(-1.13)$ \\
Leverage & $-0.02^{*}$ \\
& $(-1.65)$ \\
Observations & 0.66 \\
Pseudo $R^{2}(\%)$ & $(1.08)$ \\
\hline
\end{tabular}




\section{Table 9: Audit fees analysis}

Panel A: Descriptive statistics for audit fees before and after FYE changes

This panel reports the audit fees during the pre and post period for firms that change away and to a December FYE.

\begin{tabular}{lcc}
\hline & Before FYE Change & After FYE Change \\
\hline Change away from December & 677,564 & 553,910 \\
Change to December & 382,599 & 557,351 \\
\hline
\end{tabular}

Panel B: Regression results

This table reports the results of audit fees analysis. Column 1 examines the changes in audit fees when small firms deviate from a December year-end. Controls are limited to small firms. Test statistics (two-sided) based on robust standard errors clustered at the year and industry level are reported in parenthesis. ${ }^{* *},{ }^{* *}$, and $*$ indicate statistical significance at the $1 \%, 5 \%$, and $10 \%$ level, respectively.

\begin{tabular}{lc}
\hline & Audit Fees \\
\hline From Dec & 0.14 \\
From Dec $\times$ Post & $(0.90)$ \\
To Dec & $-0.31^{*}$ \\
& $(-1.84)$ \\
To Dec $\times$ Post & $-0.36^{* * *}$ \\
& $(-4.39)$ \\
Post & $0.27^{* * *}$ \\
& $(2.98)$ \\
Size & 0.00 \\
& $(0.23)$ \\
CR & $0.44^{* * *}$ \\
CA_TA & $(21.25)$ \\
Leverage & -0.00 \\
& $(-1.44)$ \\
Arinv & $0.49^{* * *}$ \\
Foreign & $(3.68)$ \\
Intangible & 0.02 \\
Loss & $(1.60)$ \\
& $0.34^{* * *}$ \\
Observations & $(2.94)$ \\
Year FE & 0.05 \\
Pseudo $R^{2}(\%)$ & $(1.41)$ \\
& $0.47^{* * *}$ \\
& $(3.22)$ \\
& $0.25^{* * *}$ \\
& $(8.68)$ \\
& 11,418 \\
Yes & Yes \\
& 66.89 \\
&
\end{tabular}

